\title{
PENINGKATAN MOTIVASI DAN HASIL BELAJAR MATA KULIAH PENGANTAR MANAJEMEN MELALUI METODE PROJECT BASED LEARNING
}

\author{
Titiek Ambarwati ${ }^{1}$ \\ Program Studi Manajemen, Universitas Muhammadiyah Malang ${ }^{1}$
}

\begin{abstract}
This research is a classroom action research in the introductory management course taken by the first semester students (first semester). This study was conducted to improve student motivation and learning outcomes in learning management introductory subjects. The method used through the assignment approach (project based learning, data collection techniques with tests and non-tests. Data analysis by comparing learning outcomes before and after applying project based learning learning methods. The results of the study showed an increase in student motivation and learning outcomes. During the learning process there are obstacles, namely face-to-face time constraints.
\end{abstract}

Kata Kunci: Motivation; learning outcomes; project based learning

\begin{abstract}
Abstrak
Penelitian ini merupakan penelitian tindakan kelas pada matakuliah pengantar manajemen yang ditempuh oleh mahasiswa semester awal (semester I) .Penelitian ini dilakukan untuk meningkatkan motivasi dan hasil belajar mahasiswa dalam pembelajaran matakuliah pengantar manajemen. Metode yang digunakan melalui pendekatan penugasan ( project based learning, teknik pengumpulan datanya dengan tes dan non tes. Analisis data dengan membandingkan hasil belajar sebelum dan setelah menerapakan metode pembelajaran project based learning. Hasil penelitian menunjukkan adanya peningkatan motivasi dan hasil belajar mahasiswa. Selama proses pembelajaran terdapat kendala yaitu keterbatasan waktu tatap muka.
\end{abstract}

Kata Kunci: Motivasi; hasil belajar; project based learning

\section{Pendahuluan}

Penelitian Tindakan Kelas dilakukan dengan diawali oleh suatu kajian terhadap masalah secara sistematis. Dalam proses pelaksanaan rencana yang telah disusun kemudian dilakukan suatu observasi dan evaluasi yang dipakai sebagai masukan untuk melakukan refleksi atas apa yang terjadi pada tahap pelaksanaan. Hasil dari proses refeksi ini kemudian melandasi upaya perbaikan dan peryempurnaan rencana tindakan berikutnya. Tahapan-tahapan di atas dilakukan berulang-ulang dan berkesinambungan sampai suatu kualitas keberhasilan tertentu dapat tercapai.

Penelitian Tindakan Kelas sangat bermanfaat bagi dosen untuk meningkatkan mutu proses dan hasil pembelajaran di kelas. Dengan melaksanakan tahap-tahap Penelitian Tindakan Kelas, dosen dapat menemukan solusi dari masalah yang timbul di kelas, dengan menerapkan berbagai ragam teori dan teknik pembelajaran yang relevan secara kreatif. Penelitian Tindakan Kelas merupakan suatu penelitian yang mengangkat masalah-masalah aktual yang dihadapi oleh dosen di lapangan. Dengan melaksanakan Penelitian Tindakan Kelas, dosen mempunyai peran ganda : praktisi dan peneliti.

Saat ini pembelajaran kita masih lebih terfokus pada hasil belajar berupa pengetahuan (knowledge) semata. Itupun sangat dangkal, hanya sampai pada tingkatan ingatan dan pemahaman dan belum banyak menyentuh aspek aplikasi. Ini berarti pada umumnya, pembelajaran belum mengajak mahasiswa untuk menerapkan, mengolah setiap unsur-unsur konsep yang dipelajari dan belum mengajak mahasiswa berpikir kritis terhadap konsep-konsep dan prinsip-prinsip yang telah dipelajarinya. Sementara itu, aspek keterampilan (psikomotor) dan sikap (attitude) juga banyak terabaikan sehingga pembelajaran tentunya harus diubah dari kecenderungan lama (satu arah) agar menjadi lebih interaktif (multi arah). Pembelajaran yang selama ini dilaksanakan belum bisa memotivasi mahasiswa untuk mendapatkan hasil pembelajaran yang optimal,

Melalui model pembelajaran ini, siswa juga akan dapat diharapkan menjadi lebih termotivasi dan lebih aktif menyelidiki (belajar) dengan menyajikan dunia nyata (bukan abstrak) kepada mereka. Di dalam model pembelajaran ini, mahasiswa akan bekerja secara tim (berkelompok) kooperatif dan mengubah pemikiran faktual semata menjadi pemikiran yang lebih kritis dan analitis sehingga hasil dari pembelajaran pengantar manajemen dapat lebih baik dari sebelumnya. Model pembelajaran berbasis proyek (Project

\footnotetext{
1 ambarwati.titiek@gmail.com
} 
Based Learning) merupakan salah satu model pembelajaran yang dapat digunakan oleh pendidik sehingga secara otomatis juga menggunakan pendekatan saintifik (scientific approach) dalam pembelajarannya. Pendekatan saintifik adalah pendekatan pembelajaran di mana mahasiswa memperoleh pengetahuan berdasarkan cara kerja ilmiah. Melalui pendekatan saintifik ini mahasiswa akan diajak meniti jembatan emas sehingga ia tidak hanya mendapatkan ilmu pengetahuan (knowledge) semata tetapi juga akan mendapatkan keterampilan dan sikap-sikap yang dibutuhkan dalam kehidupannya kelak.

Pembelajaran mata kuliah pengantar manajemen merupakan mata kuliah dasar yang diajarkan di jurusan manajemen FEB-UMM. Standart kompetensi dari matakuliah ini adalah memberikan kemampuan bagi mahasiswa untuk ( 1) menguasai konsep teoritis, metode dan analisis fungsi manajemen (Perencanaan, Pengorganisasian, Pengarahan dan Pengendalian) pada berbagai jenis organisasi. (2) Mampu merumuskan fungsi manajemen (Perencanaan, pengorganisasian, Pengarahan dan Pengendalian) pada berbagai tipe organisasi. Kompetensi ini sangat berguna bagi mahasiswa jurusan manajemen sebagai calon manajer untuk melihat penerapan ilmu pengantar manajemen secara nyata di lapangan. Mengingat pentingnya penguasaan kompetensi yang diberikan mata kuliah pengantar manajemen perlu diupayakan suatu penelitian terapan di kelas ( penelitian Tindakan Kelas ) berupa model pembelajaran yang mampu meningkatkan minat dan motivasi mahasiswa yang pada akhirnya dapat meningatkan prestasi belajar / hasil belajar mahasiswa. Dengan menerapakan penelitian tindakan kelas berbasis proyek maka diharapkan adanya peningkatan motivasi dan hasil belajar mahasiswa pada mata kuliah pengantar manajemen melalui model pembelajaran berbasis proyek ( Project based learning ).

\section{Metode Penelitian}

Penelitian ini merupakan penelitian tindakan kelas bagi mahaiswa yang menempuh mata kulaiah pengantar manajemen semester ganjil 2017 /1018 sesuai dengan jam dan jadwal perkuliahan. Penelitian ini dilaksanakan pada semester ganjil 2017/2018 (bulan September 2017 sampai dengan Januari 2018. Pada mahasiswa semester I jurusan manajemen Fakultas ekonomi Bisnis Universitas Muhammadiyah Malang. Pengumpulan data dilakukan dengan tes dan non tes. Untuk mengetahui pemahaman kognitip mahasiswa dilakukan dengan tes melalui ujian tengah semester dan ujian akhir semester. Perubahan sikap /perilaku mahasiswa yang meliputi ketepatan waktu pengumpulan tugas,presentasi makalah dan tingkat partisipasi dalam pembelajaran pengantar manajemen dilakukan dengan non tes.Adapun analisis data dengan menggunakan analisis secara deskriptif komperatif deskriftif kualitatif. Analisis data dengan menggunakan deskriptif komparatif yaitu membandingkan nilai tes nilai tes setelah siklus 1 , dan nilai tes setelah siklus 2. Sedangkan data hasil observasi dianalisis secara deskriptif kualitatif.

\section{Hasil dan Pembahasan}

Hasil penelitian diuraikan dalam tahapan yang berupa siklus-siklus pembelajaran yang dilakukan dalam kegiatan pembelajaran di kelas. Dalam penelitian ini pembelajaran dilakukan dalam dua siklus, seperti uraian di bawah ini. Pada kondisi awal, peneliti masih belum menerapkan pendekatan Project Based Learning, jadi pendekatan yang digunakan masih konvensional. Namun juga menggunakan empat tahapan dalam pembelajaran, yaitu: perencanaan (planning), pelaksanaan (acting), observasi (observing), dan refleksi (refecting). Metode yang digunakan adalah: ceramah, diskusi, tanya jawab. Suasana pembelajaran pada kondisi awal, kurang "hidup". Interaksi antara peserta didik dengan penyaji sangat minim, sehingga suasana terlihat agak beku.

Hasil belajar mahasiswa peserta mata kuliah pengantar manajemen pada kondisi awal, secara rinci, terurai pada tabel di bawah ini.

Tabel 2 Hasil Tes Kondisi Awal

\begin{tabular}{|c|c|c|}
\hline No & $\underline{\text { NIM }}$ & Nilai \\
\hline 1 & 0166 & 55 \\
\hline 2 & 0172 & 55 \\
\hline 3 & 0173 & 55 \\
\hline 4 & 0193 & 50 \\
\hline 5 & 0194 & 50 \\
\hline 6 & 0195 & 50 \\
\hline 7 & 0199 & 55 \\
\hline 8 & 0200 & 45 \\
\hline 9 & 0201 & 55 \\
\hline 10 & $\underline{0202}$ & $\underline{45}$ \\
\hline
\end{tabular}




\begin{tabular}{lll}
\hline No & NIM & Nilai \\
\cline { 1 - 1 } 11 & 0203 & 55 \\
12 & 0206 & 55 \\
13 & 0207 & 50 \\
14 & 0208 & 55 \\
15 & 0211 & 55 \\
16 & 0212 & 45 \\
17 & 0214 & 45 \\
18 & 0216 & 45 \\
19 & 0218 & 55 \\
20 & $\underline{0220}$ & $\underline{55}$ \\
\hline
\end{tabular}

Dari keseluruhan data nilai di atas, dapat disimpulkan bahwa nilai rata-rata hasil belajar peserta mata kuliah Pengantar Manajemen pada kondisi awal, adalah 55 dengan kategori "rendah".

\section{Deskripsi Hasil Siklus I}

Siklus 1 terdiri atas empat tahap, yaitu: Perencanaan (Planning), Pelaksanaan (Acting), observasi (Observing), dan Refleksi (Refecting).

1) Perencanaan (Planning)

a. Membuat rencana kegiatan awal (apersepsi), kegiatan inti (pokok), dan kegiatan penutup.

b. Menyiapkan soal tes dan lembar pengamatan (observasi)

2) Pelaksanaan (Acting)

a. Pada siklus 1, menggunakan pendekatan Project based Learning (PBL), dengan metode-metode: demonstrasi, diskusi, tanya jawab, kerja kelompok

b. Selanjutnya semua mahasiswa mengimplementasikan project based learning dalam pembelajaran.

c. Presentasi kelompok dilakukan secara bergantian,

3) Observasi (Observing)

a. Hasil pembelajaran mata kuliah Pengantar Manajemen yang teramati, secara umum peserta dapat memahami apa yang dimaksud dengan "pembelajaran berbasis proyek /penugasani". Namun mereka masih belum bisa mengimplementasi secara efektif dalam pembelajaran.

b. Presentasi yang dilakukan mahasiswa peserta mata kuliah Pengantar Manajemen tampak masih canggung.

c. Untuk peserta yang tidak melakukan presentasi berperan menjadi peserta (audience), mereka dapat memerankannya dengan baik.

d. Hasil pengamatan menunjukkan bahwa sebagian besar mahasiswa peserta mata kuliah Pengantar Manajemen dalam menyajikan materi masih kurang tingkat pemahamannya terhadap materi yang telah disajikan.

e. Keseluruhan hasil belajar yang dicapai oleh mahasiswa peserta mata kuliah Pengantar Manajemen, secara rinci diuraikan di bawah ini.

Tabel 3. Hasil Tes pada Siklus I

\begin{tabular}{|c|c|c|}
\hline No & NIM & Nilai \\
\hline 1 & 0166 & 70 \\
\hline 2 & 0172 & 70 \\
\hline 3 & 0173 & 60 \\
\hline 4 & 0193 & 70 \\
\hline 5 & 0194 & 60 \\
\hline 6 & 0195 & 75 \\
\hline 7 & 0199 & 50 \\
\hline 8 & 0200 & 60 \\
\hline 9 & 0201 & 75 \\
\hline 10 & 0202 & 60 \\
\hline 11 & 0203 & 70 \\
\hline 12 & 0206 & 70 \\
\hline 13 & $\underline{0207}$ & 60 \\
\hline
\end{tabular}




\begin{tabular}{lll}
14 & 0208 & 70 \\
15 & 0211 & 70 \\
16 & 0212 & 70 \\
17 & 0214 & 65 \\
18 & 0216 & 75 \\
19 & 0218 & 65 \\
20 & $\underline{0220}$ & $\underline{70}$ \\
\hline
\end{tabular}

Dari keseluruhan data nilai di atas, dapat disimpulkan bahwa nilai rata-rata hasil belajar peserta mata kuliah Pengantar Manajemen adalah 67 dengan kategori "cukup".

4) Refleksi (reflecting)

Terdapat suatu peningkatan hasil saat implementasi "pembelajaran berbasis proyek (project based learning)", namun masih relatif kecil. Nominal peningkatan tersebut, dari nilai rata-rata 55 menjadi 67

Tabel 4.Perbandingan Kondisi Awal dengan Siklus 1

\begin{tabular}{cccc}
\hline No & NIM & Tahap Awal & Siklus 1 \\
\hline 1 & 0166 & 55 & 70 \\
2 & 0172 & 55 & 70 \\
3 & 0173 & 55 & 60 \\
4 & 0193 & 50 & 70 \\
5 & 0194 & 50 & 60 \\
6 & 0195 & 50 & 75 \\
7 & 0199 & 55 & 50 \\
8 & 0200 & 45 & 60 \\
9 & 0201 & 55 & 75 \\
10 & 0202 & 45 & 60 \\
11 & 0203 & 55 & 70 \\
12 & 0206 & 55 & 70 \\
13 & 0207 & 50 & 60 \\
14 & 0208 & 55 & 70 \\
15 & 0211 & 55 & 70 \\
16 & 0212 & 45 & 70 \\
17 & 0214 & 45 & 65 \\
18 & 0216 & 45 & 75 \\
19 & 0218 & 55 & 65 \\
20 & 0220 & 55 & 70 \\
\hline
\end{tabular}

Tabel diatas menunjukkan adanya perubahan nilai setlah dilakukan tahapan untuk siklus 1 . Ada peningkatan nilai pada setiap mahasiswa serta rata-rata peningkatannya melebihi yang diharapkan.

\section{Penerapan Siklus 2}

1) Perencanaan (Planning)

a. Membuat rencana kegiatan awal (apersepsi), kegiatan inti (pokok), dan kegiatan penutup.

b. Menyiapkan soal tes dan lembar pengamatan (observasi)

2) Pelaksanaan (Acting)

a. Pada siklus 2, menggunakan pendekatan Project based Learning (PBL), dengan metodemetode: diskusi, tanya jawab, kerja kelompok

b. Selanjutnya semua mahasiswa mengimplementasikan project based learning dalam pembelajaran.

c. Presentasi kelompok dilakukan secara bergantian,

3) Observasi (Observing)

a. Hasil pembelajaran mata kuliah Pengantar Manajemen yang teramati, secara umum peserta dapat memahami materi apa yang ditugaskan dengan menggunakan "pembelajaran berbasis 
proyek /penugasan". Mereka sudah bisa mengimplementasi secara efektif dalam pembelajaran.

b. Presentasi yang dilakukan mahasiswa peserta mata kuliah Pengantar Manajemen semakin percaya diri.

c. Untuk peserta yang tidak melakukan presentasi berperan menjadi peserta (audience), mereka dapat berpartisipasi dengan lebih baik.

d. Hasil pengamatan menunjukkan bahwa sebagian besar mahasiswa peserta mata kuliah Pengantar Manajemen dalam menyajikan materi lebih memahami dan menguasai terhadap materi yang telah disajikan.

e. Keseluruhan hasil belajar yang dicapai oleh mahasiswa peserta mata kuliah Pengantar Manajemen mengalami peningkatan.

4) Refleksi (reflecting)

Terdapat suatu peningkatan hasil saat implementasi "pembelajaran berbasis proyek (project based learning)". Adapun peningkatan tersebut disajikan dalam tabel 5.

Tabel 5. Perbandingan Kondisi Awal dengan Siklus 1

\begin{tabular}{ccccc}
\hline No & NIM & Tahap Awal & Siklus 1 & Siklus 2 \\
\hline 1 & 0166 & 55 & 70 & 80 \\
2 & 0172 & 55 & 70 & 80 \\
3 & 0173 & 55 & 60 & 80 \\
4 & 0193 & 50 & 70 & 80 \\
5 & 0194 & 50 & 60 & 70 \\
6 & 0195 & 50 & 75 & 80 \\
7 & 0199 & 55 & 50 & 80 \\
8 & 0200 & 45 & 60 & 70 \\
9 & 0201 & 55 & 75 & 80 \\
10 & 0202 & 45 & 60 & 75 \\
11 & 0203 & 55 & 70 & 75 \\
12 & 0206 & 55 & 70 & 75 \\
13 & 0207 & 50 & 60 & 70 \\
14 & 0208 & 55 & 70 & 75 \\
15 & 0211 & 55 & 70 & 80 \\
16 & 0212 & 45 & 70 & 85 \\
17 & 0214 & 45 & 65 & 85 \\
18 & 0216 & 45 & 75 & 80 \\
19 & 0218 & 55 & 65 & 75 \\
20 & 0220 & 55 & 70 & 75 \\
\hline
\end{tabular}

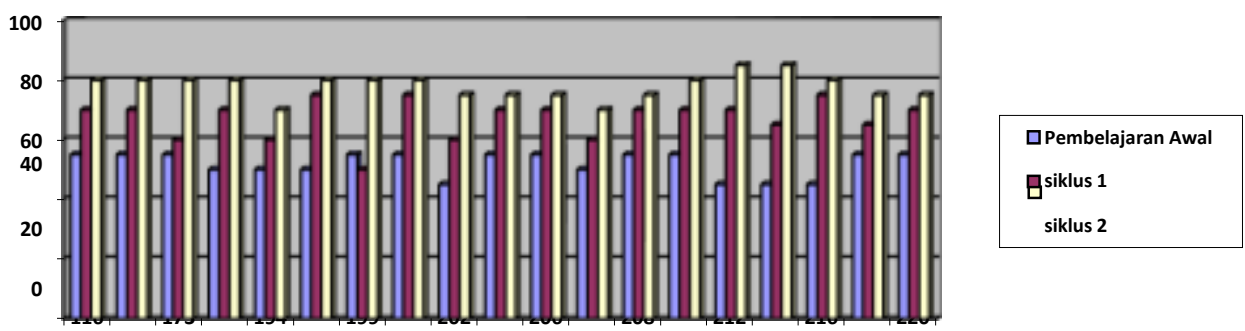

Gambar 2. Hasil Perbandingan Pembelajaran Awal, Silus 1 dan Siklus 2

Kenaikan nilai berdasar dari keaktifan mahasiswa dikelas, dilihat dari partisipasi, presentasi, dan kerja tim yang ditunjukkan dari makalah yang disusun. Dalam proses pembelajaran dikelas, masing-masing mahasiswa duduk berdasarkan kelompoknya untuk melakukan diskusi terkait tugas yang diberikan. Ketika kelompok lain presentasi, setiap mahasiswa tetap duduk sesuai dengan kelompok masing-masing untuk 
mendiskusikan materi presentasi dari kelompok lain baik berupa pertanyaan, sanggahan, maupun tambahan. Pada saat presentasi mahasiswa dimotivasi untuk saling melengkapi jawaban atas pertanyaanpertanyaan kelompok lain, sehingga didapatkan jawaban yang lebih lengkap. Kelompok yang memiliki anggota pasif, koordinator dari kelompok memotivasi anggotanya agar berperan aktif dalam presentasi, sehingga tercipta kekompakan dalam tim. Didalam proses pembuatan makalah, masing-masing anggota menyampaikan terkait materi yang ditugaskan didalam kelompok sehingga dari sharing antar anggota didapatkan hasil draft penyusunan makalah yang lebih lengkap.

Dosen sebagai fasilitator, membantu mahasiswa untuk memaksimalkan kemampuan serta ikut memotivasi agar setiap mahasiswa aktif didalam proses pembelajaran. Apabila ada mahasiswa yang masing kurang aktif, maka Dosen berperan untuk memberi kesempatan mahasiswa tersebut untuk memberikan pertanyaan atau masukan serta sanggahan. Setiap akhir presentasi kelompok menyimpulkan hasil presentasi dan Dosen melengkapi hasil presentasi pada saat itu. Dengan metode ini, suasana kelas menjadi lebih kondusif dan tercipta komunikasi dua arah.

\section{Kesimpulan dan Saran}

Implementasi Pendekatan Pembelajaran berbasis penugasan (Project Based Learning) dengan melibatkan mahasiswa peserta mata kuliah Pengantar Manajemen meningkatkan motivasi belajar mahasiswa. Pemanfaatan pendekatan pembelajaran berbasis penugasan (Project Based Learning)dapat meningkatkan hasil belajar mahasiswa.Diharapkan peneliti selanjutnya untuk melakukan penelitian dengan pembelajaran model Project Based Learning berbasis teknologi.

\section{Referensi}

Hosnan,2014.Pendekatan Saintifik dan Kontekstual dalam Pembelajaran Abad 2001.Bogor Galilea Indonesia

Steinberg, A. 1997. The Six A'a of Design Projects. http://ph.red.ru/pedsovet/GSN/pbl.Sixa.htm Thomas, J.W., dkk. 1999. Project Base Learning: A Handbook of Middle and High School Teacher.Novato CA: The Buck Institute for Education.

Wena, Made. 2010. Strategi Pembelajaran Inovatif Kontemporer (Suatu Tinjauan Konseptual Operasional). Jakarta: Bumi Aksara 